\title{
Changes in Leptin in Relation to Increased Testosterone Levels Associated with Eurycoma Longifolia Jack (Tongkat Ali) Root Extract Consumption in Male Rats
}

\author{
Ghasak Ghazi Faisal', Mainul Haque², Ghazi Faisal Najmuldeen ${ }^{3}$, Basma Ezzat Al-Ahmad", Ali Sabri Radeef , Ahmed Ghazi Alattraqchi6 \\ 'Kulliyyah of Dentistry, International Islamic University Malaysia, 25100, Kuantan, MALAYSIA. \\ 2Faculty of Medicine and Defense Health, National Defense University of Malaysia, Kem Sungai Besi, 57000 Kuala Lumpur, MALAYSIA. \\ ${ }^{3}$ Faculty of Chemical and Natural Resources Engineering, University Malaysia, Pahang, Kuantan, MALAYSIA. \\ ${ }^{4}$ Kulliyyah of Medicine, International Islamic University Malaysia, Kuantan, MALAYSIA. \\ 5Kulliyyah of Dentistry, International Islamic University Malaysia, 25100, Kuantan, MALAYSIA. \\ ${ }^{6}$ Faculty of Medicine, Medical Campus, Universiti Sultan Zainal Abidin, Jalan Sultan Mahmud, 20400 Kuala Terengganu, Terengganu, MALAYSIA.
}

\begin{abstract}
Objectives: Eurycoma longifolia jack root extract has been known for its aphrodisiac and anabolic properties. Our study aimed at investigating the effects of this extract on the serum leptin in relation to the well-known effects on testosterone levels of male rats. Methodology: Twenty-four mature male Albino Wistar rats were used in this study. The rats were divided into 3 groups; control, group A and group B. Body weight was recorded for the rats in all groups. Group A received $5 \mathrm{mg} / \mathrm{kg}$ twice daily of pure Eurycoma Longifolia root extract. Group B received $10 \mathrm{mg} / \mathrm{kg}$ twice daily of the same extract. The duration of treatment was 6 weeks at the end of which, serum leptin and testosterone levels were analyzed in all groups and body weight recorded. Results: The mean serum leptin and testosterone levels for the control were $1.13 \pm 0.13 \mathrm{ng} / \mathrm{ml}$ and $0.79 \pm 0.07 \mathrm{ng} / \mathrm{ml}$ respectively. While for group A were $1.09 \pm 0.19 \mathrm{ng} / \mathrm{ml}, 0.89 \pm 0.16 \mathrm{ng} / \mathrm{ml}$ and for Group B were $0.89 \pm 0.16 \mathrm{ng} / \mathrm{ml}, 1.75 \pm 0.1 \mathrm{ng} / \mathrm{ml}$ respectively. The rats in the treated groups showed decrease in body weight in comparison to the control which was not significant in group $A(p=0.867)$ and significant in group B ( $p=0.042)$. Statistical analysis showed that the serum leptin level of group $B$ was significantly lower than that of control group $(p=0.001)$ and group $A(p=0.03)$. On the other hand, no significant difference in serum
\end{abstract}

leptin levels was observed between the control group and group $A$. The serum testosterone level was significantly higher in group $B$ than control and group $A$ while group $A$ did not show a statistically significant difference than control. Conclusion: Eurycoma Longifolia root extract can significantly decrease serum leptin levels in relation to the rise in serum testosterone levels. Eurycoma Longifolia consumption also causes a significant decrease in total body weight pointing to the possibility of decreased body fat content.

Key words: Leptin, Testosterone, Eurycoma Longifolia Jack, Anabolic.

Correspondence :

Mainul Haque

Professor, Faculty of Medicine and Defense Health, National Defense University of Malaysia, Kem Sungai Besi, 57000 Kuala Lumpur, MALAYSIA.

Email: runurono@gmail.com

DOI: 10.5530/jyp.2017.9.8

\section{INTRODUCTION}

Leptin is a $16 \mathrm{kDa}$ protein hormone that plays a key role in regulating energy intake and energy expenditure, including appetite and metabolism, it is one of the most important adipose derived hormones. ${ }^{1}$ The $\mathrm{Ob}$ (Lep) gene is located on chromosome 7 in humans. ${ }^{2}$ It is manufactured primarily in the adipocytes of white adipose tissue. Leptin reduces appetite as a circulating signal and the level of circulating leptin is directly proportional to the total amount of fat in the body. ${ }^{3}$ In spite of its function to regulate energy intake and expenditure, obese individuals generally exhibit an unusually high circulating concentration of leptin and this is mainly due to the increase amount of total body fat. ${ }^{4}$ Leptin is inversely related to testosterone and numerous studies have documented this relationship..$^{5-7}$ Studies done on hypo-gonadal men with very low levels of testosterone showed high levels of leptin that declined significantly upon administration of exogenous testosterone indicating that testosterone is a modulator of leptin. ${ }^{8}$ Other studies have also shown that there is a decrease in serum testosterone level in obese men and significant rise in serum leptin levels. ${ }^{9-13}$ It also has been reported that Malaysia also have similar problem of high prevalence of obesity and low fertility rate especially in men. ${ }^{14,15}$ The current study was designed to use a natural product that increases the testosterone level and by doing so will modulate the leptin level and body weight level and that is by administration of Eurycoma longifolia (EL) jack root extract.

EL Jack is a well-known Asian medicinal plant that can be found in the primary and secondary evergreen and mixed deciduous forests in Burma, China, Thailand, Malaysia, Sumatra, Borneo and the Philippines. ${ }^{16}$ Different parts of this plant, especially the roots have been used traditionally for decades to treat fever, high blood pressure and fatigue. ${ }^{17}$ Other effects include antimalarial, ${ }^{18}$ cytotoxic ${ }^{19}$ and antiulcer ${ }^{20}$ activities. The main use of this plant however, is as an aphrodisiac as the root extracts have been proved to increase the serum testosterone level and general body strength and improve sexual activity in males. ${ }^{21,22}$ Recently, interest has turned to another effect of this plant; the anabolic potential which has been confirmed in the animal model, when the size and weight of a muscle was measured in treated and untreated rats of equal size. Results showed there is a significant increase in muscle size. ${ }^{23}$ It is well documented that the consumption of EL root extract leads to rise in serum testosterone level. ${ }^{24}$ However there are no published studies on the effect of EL root extract on leptin hormone. This study aimed to investigate the changes in leptin hormone and body weight in relation to the increase in testosterone level in rats treated with EL root extract. 


\section{MATERIALS AND METHODS}

Twenty-four mature male Albino Westar rats weighing between 220-250 gm were used. The sample size was calculated according to resource equation method. ${ }^{25}$ They were housed in standard cages, and were maintained under controlled laboratory conditions $\left(27-30^{\circ} \mathrm{C}\right.$ and $60 \%$ relative humidity) on a $12 \mathrm{~h}$ light/dark cycle. Commercial rat pellets and water were always available. The animals were accustomed to the housing conditions for one week before starting the treatment. The standardized aqueous dried root extract of EL, in the form of powder was purchased from L. Jack Sdn. Bhd. company in Malaysia with a certificate of concentration and pureness. The extract was dissolved in pure water till the desired concentration was obtained. Analysis of Testosterone $(\mathrm{T})$ and leptin (L) was done using ELIZA kits number KA0309 and KA0026 respectively which are manufactured by Abnova and purchased from Axon Scientific Sdn. Bhd. Malaysia. The rats were divided into three groups ( $\mathrm{n}=8)$; control, low dose (G1) and high dose (G2). Body weight was recorded for the rats in all groups. After the rats were allowed to adjust to their environment, G1 and G2 started to be force fed the extract solution via an oral gavage, while control group was fed plain water. All treatments were administered daily at $0900 \mathrm{hrs}$ and $2100 \mathrm{hrs}$ and continued for six weeks. Group A received the extract at a dose of $5 \mathrm{mg} / \mathrm{kg}$ twice daily and group B received the same extract at a dose of $10 \mathrm{mg} / \mathrm{kg}$ twice daily for the same duration. After six weeks of treatment, body weight was measured again and blood samples were obtained from the rats in all groups through the tail veins and analyzed for (T) and (L) hormone levels. Statistical Analysis: Statistical analysis of the data was carried out using Statistical Package for Social Sciences (SPSS) version 20.0. One-way analysis of variance (ANOVA) and the Tukey post hoc test for average comparison were done. Mean values \pm standard deviation (S.D) were calculated. Significance was defined as $p<0.05$. Ethical Approval: This research was approved by the Kulliyyah of Dentistry research committee and the research management center, International Islamic University of Malaysia, Kuantan Campus, 2100 Kuantan, Pahang, Malaysia.

\section{RESULTS}

Results of the current study showed that mean serum leptin level decreased slightly in group A as compared to the control group and this change was not statistically significant $(\mathrm{p}=0.659)$. At the same time, the mean testosterone level slightly raised as compared to the control group however the change was not significant $(\mathrm{p}=0.732)$ (Table 1). Upon increasing the dose of EL root extract to $10 \mathrm{mg} / \mathrm{kg}$ twice daily for group B, the mean value of serum leptin level was $0.89 \mathrm{ng} / \mathrm{ml}$ which is significantly lower than the control group $(\mathrm{p}=0.001)$. This highly significant decrease in leptin level was accompanied by a significant rise in the testosterone level $(p=0.001)$ (Table 1 and Figure 1). In comparing the levels of leptin and testosterone between groups A and B, the results showed that both the decrease in leptin and increase in testosterone are significantly different in group B than group A (Table 2). Regarding the changes in body weight in comparison to the control group, group A showed a slight non-significant reduction in body weight $215 \pm 20 \mathrm{gm}$, while there was a significant reduction in body weight in group B $195 \pm 15$ gm $(\mathrm{p}<0.04)$ (Table 1 and Figure 2).

\section{DISCUSSION}

The results of our study we have found that EL extract can affect the leptin levels. The results also indicate that the change of leptin level may be dependent on the rise of testosterone that occurs in group B. This is in line with previous studies that proved the negative correlation between leptin and testosterone. ${ }^{4}$ The body weight also showed significant reduc-
Table 1: Serum Testosterone and Leptin Concentrations and Body Weight in Control, Group A and Group B. The Values Are Presented as the Mean \pm Standard Deviation.

\begin{tabular}{cccccc}
\hline & Control & Group A & P value & Group B & p value \\
\hline Leptin ng/ml & $1.13 \pm 0.13$ & $1.09 \pm 0.19$ & 0.659 & $0.89 \pm 0.21$ & 0.001 \\
$\begin{array}{c}\text { Testosterone } \\
\text { ng/ml }\end{array}$ & $0.79 \pm 0.07$ & $0.89 \pm 0.16$ & 0.732 & $1.75 \pm 0.10$ & 0.001 \\
$\begin{array}{c}\text { Body weight } \\
\text { gm }\end{array}$ & $220 \pm 30$ & $215 \pm 20$ & 0.867 & $195 \pm 15$ & 0.042 \\
\hline
\end{tabular}

Table 2: Comparison Between Serum Leptin and Testosterone in Group A and B. The Values Are Presented as The Mean \pm Standard Deviation.

\begin{tabular}{cccc}
\hline Hormone & Group A & Group B & p value \\
\hline Leptin ng/L & $1.09 \pm 0.19$ & $0.89 \pm 0.21$ & 0.03 \\
Testosterone $\mathrm{ng} / \mathrm{ml}$ & $0.89 \pm 0.16$ & $1.75 \pm 0.10$ & 0.001 \\
\hline
\end{tabular}

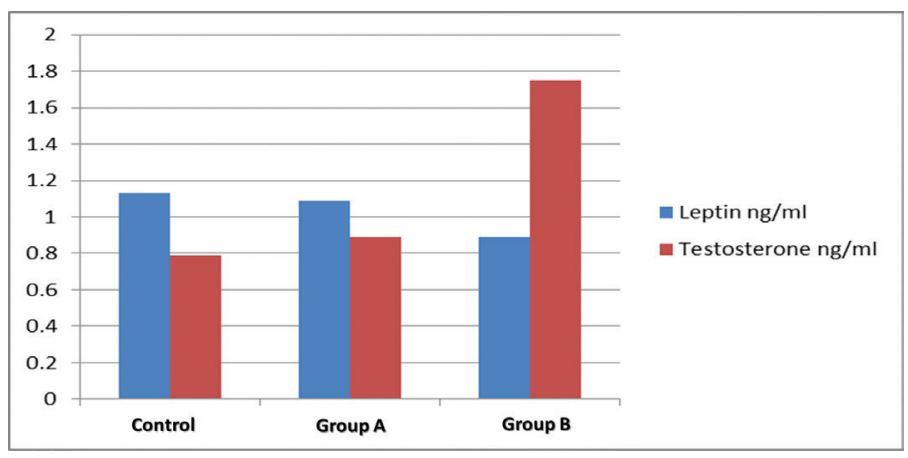

Figure 1: Bar Chart Showing the Levels of Leptin and Testosterone in the Studied Groups.

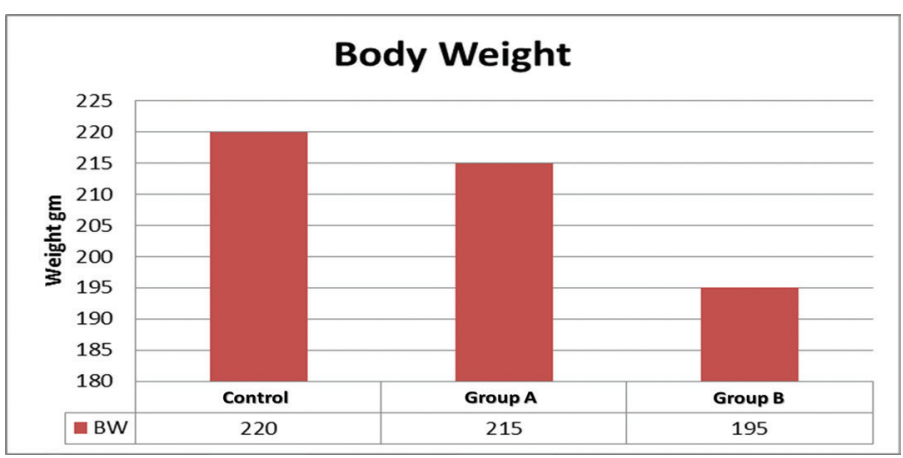

Figure 2: Bar Chart Showing the Changes in Body Weight in the Tested Groups.

tion in group B and this is in agreement with Solomon et al who stated that consumption of EL extract lead to significant decrease in body weight and omentum fat in male rats. ${ }^{26}$ This means that the decrease in leptin levels with EL extract consumption may be due to the decrease in the total amount of fat. This reduction in body fat occurs due to increase in testosterone levels as stated in a previous study that administration of testosterone leads to the decrease in leptin and reduction in weight and waist circumference in men. ${ }^{24}$ Testosterone affects leptin level through reduction in visceral adipose tissue ${ }^{27}$ and reduces lipoprotein lipase (LPL) activity and associated uptake of triglycerides into visceral adipose cells, thereby reducing the size of these cells thus decreasing leptin production. EL extract is inducing endogenous testosterone 
production which will have the same effect as administration of exogenous testosterone with a difference in that this testosterone is natural and has fewer side effects. ${ }^{28}$ This natural way to increase testosterone and reduce leptin may prove to be useful in older men with lower testosterone levels and obesity.

\section{CONCLUSION}

EL root extract significantly reduces serum leptin level and this reduction is related to the significant increase in serum testosterone level. The reduction in serum leptin may be due to decrease in total amount of body fat as demonstrated by the significant decrease in total body weight. Well controlled prospective studies are advocated to support common Malaysian with obesity and low fertility level.

\section{ACKNOWLEDGEMENT}

This study was funded by a research grant from the International Islamic University Malaysia Endowment fund no. EDW B 110660544, September 2011. We would like to express our gratitude for providing necessary fund to the International Islamic University Malaysia.

\section{CONFLICT OF INTEREST}

The authors declare no conflict of interest in conducting this research.

\section{ABBREVIATIONS USED}

EL: Eurycoma longifolia jack; T: Testosterone; L: Leptin.

\section{REFERENCES}

1. Zhang Y, Proenca R, Maffei M, Barone M, Leopold L, Friedman JM. Positional cloning of the mouse obese gene and its human homologue. Nature. 1994;372(6505):425-32.

2. Green ED, Maffei M, Braden V , Proenca R, DeSilva $U$, Zhang $Y$, et al. The human obese (OB) gene: RNA expression pattern and mapping on the physical, cytogenetic, and genetic maps of chromosome 7. Genome Res. 1995;5(1):5-12.

3. Frederich RC, Hamann A, Anderson S, Löllmann B, Lowell BB, Flier JS. Leptin levels reflect body lipid content in mice: Evidence for diet-induced resistance to leptin action. Nat Med. 1995:1(12):1311-4.

4. Considine RV, Sinha MK, Heiman ML, Kriauciunas A, Stephens TW, Nyce MR et al. Serum immunoreactive-leptin concentrations in normal-weight and obese humans. N Eng J Med. 1996;334(5):292-5

5. Thomas T, Burguera B, Melton LJ $3^{\text {rd }}$, Atkinson EJ, O'Fallon WM, Riggs BL, et al. Relationship of serum leptin levels with body composition and sex steroid and insulin levels in men and women. Metabolism. 2000; 49(10):1278-84.

6. Perry HM $3^{\text {rd }}$, Miller DK, Patrick P, Morley JE. Testosterone and leptin in older African-American men: relationship to age, strength, function, and season. Metabolism. 2000;49(8):1085-91.

7. Luukkaa V, Pesonen U, Huhtaniemi I, Lehtonen A, Tilvis R, Tuomilehto J, et al. Inverse correlation between serum testosterone and leptin in men. J Clin Endocrinol Metab. 1998;83(9):3243-6.

8. Ogura T, Tobe K, MimuraY, Otsuka F, YamauchiT, Imai A, et al. Testosterone modulates serum leptin concentrations in a male patient with hypothalamic hypogonadism. J Endocrinol Invest. 2000;23(4):246-50.
9. Osuna JA, Gómez-Pérez R, Arata-Bellabarba G, Villaroel V. Relationship between $\mathrm{BMI}$, total testosterone, sex hormone-binding-globulin, leptin, insulin and insulin resistance in obese men. Arch Androl. 2006;52(5):355-61.

10. Söderberg $S$, Olsson $T$, Eliasson $M$, Johnson $O$, Brismar $K$, Carlström $K$, et al. A strong association between biologically active testosterone and leptin in non-obese men and women is lost with increasing (central) adiposity. Int J Obes Relat Metab Disord. 2001;25(1):98-105

11. Isidori AM, Caprio M, Strollo F, Moretti C, Frajese G, Isidori A, et al. Leptin and androgens in male obesity: evidence for leptin contribution to reduced androgen levels. J Clin Endocrinol Metab. 1999;84(10):3673-80.

12. Ozata M, Oktenli C, Bingol N, Ozdemir IC. The effects of metformin and diet on plasma testosterone and leptin levels in obese men. Obes Res. 200;9(11):662-7.

13. Zhao J, Zhai L, Liu Z, Wu S, Xu L. Leptin Level and Oxidative Stress Contribute to Obesity-Induced Low Testosterone in Murine Testicular Tissue. Oxidative Med Cellular Longevity. 2014; 2014: Article ID 190945, 14 pages.

14. Noor MI, Koon PB, Hashim Z. Strategy for the Prevention of Obesity Malaysia Malaysian Association for the Study of Obesity, 2005. Available at: http://www. maso.org.my/spom/spom_intro.pdf [Accessed on 21-June-2016]

15. Malaysian Diabetes Association. Clinical Practice Guidelines On Management of Obesity2003. Available at: https://www.google.com/search? site=\&source= $h p \& q=o b e s i t y+l o w+f e r t i l i t y+$ malaysia\&oq=obesity+low+fertility+malaysia\& gs_l=hp.3...1615.32140.0.33127.31.31.0.0.0.0.146.1811.30j1.31.0...0...1c.1.64 hp..0.27.1595.0..0j35i39j0i131j0i20j0i22i30j33i21.UwfLly37QFw [Accessed on 21-June-2016]

16. Osman A, Jordan B, Lessard PA, Muhammad N, Haron MR, Riffin NM, et al. Genetic diversity of Eurycoma longifolia inferred from single nucleotide polymorphisms. Plant Physiol. 2003;131(3):1294-301.

17. Bhat R, Karim AA. Tongkat Ali (Eurycoma longifolia Jack): A review on its ethnobotany and pharmacological importance. Fitoterapia. 2010;81(7):669-79.

18. Chan KL, O'Neill MJ, Phillipson JD, Warhurst DC. Plants as sources of antimalarial drugs. Part 3. Eurycoma Longifolia Jack. Planta Med. 1986;52(2):105-7.

19. Kuo PC, Shi LS, Damu AG, Su CR, Huang CH, Ke CH, et al. Cytotoxic and antimalarial $\beta$-carboline alkaloids from the roots of Eurycoma longifolia. J Nat Prod. 2003;66(10):1324-7.

20. Tada H, Yasuda F, Otani K, Doteuchi M, Ishihara Y, Shiro M. New antiulcer quass inoids from Eurycoma longifolia. Eur J Med Chem. 1991;26(3):345-9.

21. Ang HH, Ngai TH, Tan TH. Effects of Jack on sexual qualities in middle aged male rats. Phytomedicine. 2003;10(6-7):590-3.

22. Chan $\mathrm{KL}$, Low BS, Teh $\mathrm{CH}$, Das PK. The effect of Eurycoma longifolia on sperm quality of male rats. Nat Prod Commun. 2009;4(10):1331-6.

23. Ang HH, Cheang HS. Effects of Eurycoma longifolia jack on laevator ani muscle in both uncastrated and testosterone-stimulated castrated intact male rats. Arch Pharm Res. 2001;24(5):437-40.

24. Tambi MIBM, Imran MK, Henkel RR. Standardized water-soluble extract of Eurycoma longifolia, Tongkat Ali, as testosterone booster for managing men with late-onset hypogonadism. Andrologia. 2012;44(Suppl.1):226-30

25. Festing MF, Altman DG. Guidelines for the design and statistical analysis of experiments using laboratory animals. ILAR J. 2002;43(4):244-58.

26. Solomon MC, Erasmus N, Henkel RR. In vivo effects of Eurycoma longifolia Jack (Tongkat Ali) extract on reproductive functions in the rat. Andrologia. 2014;46(4):339-48.

27. Kapoor D, Clarke S, Stanworth R, Channer KS, Jones TH. The effect of testosterone replacement therapy on adipocytokines and C-reactive protein in hypogonadal men with type 2 diabetes. Eur J Endocrinol. 2007;156(5):595-602.

28. Rhoden EL, Morgentaler A. Risks of testosterone-replacement therapy and recommendations for monitoring. N Eng J Med. 2004;350(5):482-92.

Article History: Submission Date: 21-06-16; Revision Date: 15-07-16; Accepted Date: 07-08-16.

Cite this article: Faisal GG, Haque M, Najmuldeen GF, Al-Ahmad BE, Radeef AS, Alattraqchi AG. Changes in Leptin in Relation to Increased Testosterone Levels Associated with Eurycoma Longifolia Jack (Tongkat Ali) Root Extract Consumption in Male Rats. J Young Pharm. 2017:9(1):40-2. 